\title{
HEALTH AND THE MILLENNIUM DEVELOPMENT GOALS. THE NIGERIAN PERSPECTIVE
}

\author{
* E.J. Enabudoso* E.P. Gharoro,* G.O. Ikena and **B. Abhulimhen-Iyoha \\ Department of ${ }^{*}$ Obstetrics and Gynaecology, ${ }^{\star *}$ Child Health, University of Benin \\ Teaching Hospital, Benin City, Edo State, Nigeria
}

\section{INTRODUCTION}

The turn of the last century ushered in a new millennium - a millennium with its hopes, aspirations and fears for its billions of inhabitants. Towards the end of the last century, various far-reaching agreements were made at the numerous conferences of the United Nations with its collaborating agencies. The enormous burden of poverty, hunger, ill health, environmental degradation and natural disease posed significant threat to peace, stability and development and hence continued human existence ${ }^{1}$. The fears were palpable and so were the efforts at combating the problems.

In September 2000, on the heels of the dawn of the new millennium, the world witnessed the largest-ever gathering of Heads of State. This gathering, tagged the UN millennium summit in New York, USA, endorsed the UN millennium declaration which was endorsed by the 189 countries including Nigeria. The declaration was then translated into a roadmap setting out goals to be reached by 2015. These goals, eight in number, became known as the Millennium Development Goals (the MDGs). The MDGs represent a worldwide collaborative effort to reduce poverty and hunger, tackle ill-health, gender inequity, lack of education, lack of access to clean water and environmental degradation ${ }^{2,3}$.

\section{Corresponding author:}

Dr. Enabudoso Ehigha. Department of Obstetrics and Gynaecology, University of Benin Teaching Hospital, PMB IIII, Benin City, Edo State

E-mail: drehigha@yahoo.com
Notable conferences in health and development leading to the millennium summit include: the International Conference on Population and Development (ICPD) Cairo 1994; the $4^{\text {th }}$ World Conference on women (4WCW) Beijing 1995; 5 years post 4 WCW (4 WCW + 5) Washington DC 2000; Roll back malaria summit (RBM) Abuja 2000; etc. Most of these summits and conferences touched on various areas affecting development, health, population, economy and human environment and existence. They set various targets and strategies to achieve these. The millennium summit was a revolutionary attempt to synthesize these various goals and targets into what became the MDGs. The goals set for 2015 were based on the 1990 figures $^{2-5}$.

The magnitude of problems facing mankind is enormous ${ }^{1,6}$. These range from the natural to man-made. Natural disasters like hurricanes, floods, earthquakes and droughts have resulted in great catastrophes rendering hundreds of thousands homeless and in dire need for food, clothing, shelter and medicines. Wars, ethnic strife, racism, genocides and various conflicts have plunged many regions into perpetual poverty, disease and hunger. The overwhelming debt burden and bad governance in many of the underdeveloped countries have in no small way contributed to the precarious situation? ${ }^{7}$. Despite massive industrialization, gross inequity in wealth distribution has left a majority of mankind in want and in some cases, terrible squalor. With over 1 billion people living on less than 1 
Benin J ournal of Postgraduate Medicine Abhulimhen-Iyoha

dollar/day, and a similar number threatened by food insecurity, rising HIV and debt burden, increasing maternal and child mortality, rising unemployment and widening gap between the haves and have not, the millennium summit could not have come at a more auspicious time ${ }^{1,6,8,9}$. Nevertheless, sight must not be lost on the fact that there has been preceeding discrepancy between setting of international goals and the interpretation and implementation of policies and programmes that truly address the needs of individuals and families in our respective countries. Policies and goals need committed action for implementation ${ }^{1,7-10}$.

\section{HEALTH IMPLICATION}

According to Dr. Lee JongWook, the former Director-General of the WHO, improvements in health are essential if progress is to be made with the other Millennium Development Goals ${ }^{2,5,8}$. Health and Education are squarely at the centre of the MDGs. Three out of eight goals, eight out of eighteen targets and 18 out of 48 indicators relate directly to health ${ }^{2,3}$. Health is also an important contributor to several other goals. The cross-sectoral nature of health determinants has long been known. This knowledge has more recently evolved into a more comprehensive approach of health being addressed within a broad economic and political framework. Public health experts have long advocated that health be at the centre of development policies and efforts of responsible governments ${ }^{8,9}$. This, the MDGs have tried to achieve.

\section{Goal 1: Poverty, Hunger and Health}

The vicious cycles of poverty, ignorance and disease have long been known. Good health defines the ability to be economically and developmentally viable. To the
Enabudoso E.J . Gharoro E.P.,Ikena G.O. and ${ }^{* * B}$.

world's poor, ill health is the single most common trigger for the downward slide to poverty ${ }^{2,5}$. III health is perceived both as a cause of increased poverty and as an obstacle to escaping it. Illness can reduce reserves, cause educational setbacks, reduce productivity and lead to job loss, thereby creating or perpetuating poverty. In similar vain, the poor are more exposed to adverse personal and environmental factors, are less well nourished and less able to access health care. III health disproportionately affects poor people and helps push them into greater poverty. Conversely, better health translates into greater and more equitably distributed wealth by building human and social capital and increasing productivity.

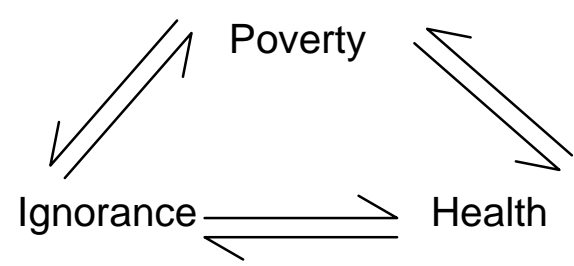

Therefore, the MDG I has an overarching goal of attaining a level of equity in the production and sharing of global and natural resources in a way that brings the majority of the population within acceptable living standards. To achieving this goal, health remains intricately indispensable.

\section{Goal 2: Universal Primary Education and}

\section{Goal 3: Gender Equity and Women Empowerment}

Better health, education and women empowerment are intricately linked. They are essential to achieving the MDGs. A child's ability to learn and attend school is 
significantly affected by health. Literacy also increases health seeking behaviour leading to improved individual and family health. Education is an essential ingredient to women empowerment and gender equity, the latter being indispensable in improving, the reproductive health standards and reducing maternal mortality.

\section{Goal 4: Reduce Child Mortality and}

\section{Goal 5: Improve Maternal Health}

These need no introduction. The sorry state of reproductive health indices in developing countries continues to send shock waves across the globe. Various efforts to date are yet to yield any significant dividend. Instead, the indices seem to even worsen. It is believed that maternal mortality rate is one of the best indicators of social development anywhere ${ }^{11}$.

\section{Goal 6: Combat HIVIAIDS, Malaria, Tuberculosis and other Diseases}

These diseases together result in more than 6 million deaths annually ${ }^{12}$. Most of these are in women and children with over 90\% occurring in underdeveloped countries. The economic impact as a result of the burden of these diseases is overwhelming $^{8,12}$. With an increasing prevalence and lack of accessibility to antiretroviral and other therapies, the future looks bleak in ravaged countries most notably in central and southern Africa. Therefore, the concerted efforts provided by the MDGs is obviously a step in the right direction.
Goal 7: Environmental Sustainability

Industrialization has inevitably led to environmental pollution and the harsh realities of adverse environmental conditions. These have negative impacts on the health of the individuals, families and communities. Communicable diseases thrive more in these adverse environmental conditions. Good sanitary and hygienic conditions, portable water supply and environmental sanitation are indispensable in the goal of universal health.

\section{Goal 8: Global Partnership}

The MDGs are a chance to make policies to increase health investments, focus on the poor, reduce inequities and build capacity. Health indices are worst in the poorest countries who also lack the wherewithal for reversing the trend ${ }^{6,13}$. Whereas policies are meant for implementation, a near impossibility in these countries with an astronomically high unmet need for adequate health, it is imperative for worldwide policy change in favour of naturally disadvantaged and poorer nations. In addition, various international agencies and drug companies need to make health provisions and improved essential drug availability in favour of the disadvantaged nations if attainment of the MDGs is to be achieved $^{14,15}$.

While the primary responsibility to achieve the MDGs rests with developing countries, international support remains critical. This is especially important in the areas of debt relief, opening up of trade favourable to poor countries, industrialization, technological assistance, employment and provision and assess to essential drugs. Fighting poverty 
Benin J ournal of Postgraduate Medicine Abhulimhen-Iyoha

must be understood to require collective responsibility ${ }^{15,16}$.

\section{The Journey so Far}

The 2005 United Nations report on the MDGs, while acknowledging some achievements, gave credence to the fears of possible non attainment in poorer countries ${ }^{17}$. The indices are staggering.

I. Millions more people have sunk deep into poverty in subSaharan Africa where the poor are getting poorer. Conflicts and disaster have further exacerbated poverty and hunger.

II. Women still form a negligible minority in business and politics in many regions of the world.

III. More than 11 million children still die annually before the age of 5 years.-many from preventable diseases.

IV. Maternal mortality still remains high and even rising in many developing countries. Rates of between 2,500 to 7,500 per 100,000 live births have been reported in parts of Nigeria.

V. AIDS remains the leading cause of premature death in subSaharan Africa and fourth largest killer in the world.

VI. Malaria and Tuberculosis continue their unabating rampage in endemic regions of sub-Saharan Africa.

VII. Almost a third of the world's population lacks access to essential medicines rising to over $50 \%$ in some of the lowest income countries of the developing world.

Overall, the data are not encouraging and suggest that majority of poor countries will not meet the health targets based on present indices $^{6,9,11,14,16,18}$. However, there are reports of pockets of encouraging achievements in some countries.
Enabudoso E.J . Gharoro E.P.,Ikena G.O. and ${ }^{* *}$ B.

- Rwanda has $49 \%$ of members of its national assembly as women. This is the highest ever.

- Uganda and Thailand are giving a very good fight to the HIVIAIDS scourge especially in the prevention of the disease.

- Uganda and Nigeria are making giant strides to improve assess to genuine medicines.

- Brazil, Senegal, Tanzania and Cameroon are noted to have improved policies that favour attainment of the MDGs.

It must be noted that the developed countries, already with high levels of development and health care are best posed to achieving the MDGs and most are already doing so $0^{5,9,17}$.

\section{DRAWBACKS OF THE MDGs}

While acknowledging the MDGs as a worthy step in the right direction, some glaring drawbacks need highlighting.

- The MDGs say nothing about strengthening health systems. According to the $\mathrm{WHO}$, building up and strengthening health systems is vital if more progress is to be made towards the MDGs $^{4,18}$. Health, as already noted, is a cornerstone to the attainment of the MDGs.

- The tactful but subtle exclusion of sexual and reproductive health (SRH) from the MDGs. Though reduction of maternal mortality in MDGs is an aspect of $\mathrm{SRH}$, an all embracing inclusion would have been more apt as appropriately highlighted by the ICPD in Cairo in 1995. The reduction of poverty, maternal and child mortality and HIVIAIDS spread are integral affirmations of the ICPD declaration on SRH. A strong commitment to $\mathrm{SRH}$ is essential for achieving not only the health related MDGs but all the $\mathrm{MDGs}^{19}$. 
- There are no specific set standards on budgetary imperatives for the attainment of the MDGs ${ }^{19}$. The MDGs are just a set of policies and lack power to compel implementation in the individual countries. Based on antecedents, policies in many developing countries never see implementation ${ }^{6,7}$.

- Non communicable diseases have no mention whatsoever in the MDGs whereas these are major causes of morbidity and mortality ${ }^{6}$.

\section{The Situation in Nigeria}

Nigeria is a signatory to the UN millennium summit declaration. The attainment of the MDGs is an obvious policy thrust of the Federal Government. It possesses an office in the presidency and various programmes of government are aimed at the various goals both directly and indirectly.

- The reform programmes which aim at eliminating waste and driving the various sectors of the economy and national life from the path of redundancy to that of progress.

- The National economic empowerment and development strategy (NEEDS).

- The National poverty eradication programme (NAPEP).

- The universal basic education programme (UBE).

- The National Health Insurance Scheme (NHIS).

- The National Action Committee on AIDS (NACA), and its associated programme for the prevention of maternal to child transmission of HIV (PMTCT) programme.

- The Role Back Malarial Programme (RBM) and its associated Insecticide Treated Nets (ITN) and policy towards improved malaria treatment with Artemisinin Combination therapy (ACT).

- Provision of Antiretroviral therapy and policy on free treatment at the various designated centres.

- The strengthening of the National Agency for Drug Administration and Control (NAFDAC).

- The recent debt relief achieved from the Paris Club of creditors.

- And many others.

Though these various policies and bodies exists, there is still palpable fear that adequate implementation may remain a mirage. Worsening health indices, poor sanitation, increasing poverty, insecurity, poor transportation electricity and water supply are just but few of the numerous ills that plague the Nigerian society. Bad governance is believed to be the bane of the country's development.

It is important to note the collaborative efforts among African countries, championed by Nigeria, to better its lot. The successes of the African Union (AU) on conflict resolution is commendable. The New partnership for African Development (NEPAD), whose implementation committee's inaugural meeting took place in Abuja, Nigeria on the $23^{\text {rd }}$ of January, 2001, is expected to work towards the prevention of conflicts and to provide political stability in the region - an imperative to development, economic growth and provision of health.

The struggle by the society of Gynaecology and Obstetrics of Nigeria (SOGON) for the passage of the Reproductive Health Bill is obviously another right step in the right direction. 
Benin J ournal of Postgraduate Medicine

Abhulimhen-Iyoha

\section{CONCLUSION}

It must be noted that there has been preceeding discrepancy between the setting of international goals and the interpretation and implementation of policies and programmes that truly address the needs of individuals and families in the various countries. The MDGs are clearly achievable and have even been described as the minimum (instead of millennium) goals required for meaningful development and stability ${ }^{5,15}$. The world has never seen as much prosperity as it is presently experiencing. A redistribution of wealth is inevitable. While it is believed that an increase aid of about $\$ 50$ billion (50 billion dollars) is needed by developing countries, governments of the world spent a whopping over $\$ 900$ billion (900 billion dollars) on arms in 2003 alone $^{5,15}$.

In the words of Kofi Annan, the UN Secretary General, we must break with business as usual. Success will require sustained action across the entire decades ${ }^{1}$.

The MDGs offer a great opportunity for provision of meaningful health to the peoples of the world. The cost of missing this opportunity will be enormous. Millions of lives that could have been saved will be lost, many freedoms that would have been secured will be denied; and we shall inhabit a more dangerous and unstable world ${ }^{5,6,15,16}$.

\section{REFERENCES}

1. Kofi Annan. United Nations' Secretary General's Message for the New Millennium. Available at http:// www.unorg/ millennium/sg/report. Assessed 12 July, 2006.
Enabudoso E.J . Gharoro E.P.,Ikena G.O. and **B.

2. World Health Organisation. Measuring Progress towards health in the Millennium Development Goals. Available at www.who.int/mdg. Assessed 10 July, 2006.

3. United Nations General Assembly. United Nations Millennium Declaration. Resolution 55/2. September 18, 2000. Available at http://www.un.org/millennium/ declaration/ares.552epdf.

4. Travis $P$, Bennett $S$, Haines $A$, Pang $T$, Bhutta $Z$, Hyder $N$, et al. Overcoming Health-Systems Constraint to achieve the MDGs. The Lancet. 2004; 364 (9437); 900 - 906.

5. Jeffrey DS. Health in the developing countries: Achieving the Millennium Development Goals. Bulletin of the World Health Organisation. 2004; 82(12).

6. Kelley Lee, Gill Walt, Haines Andy. The Challenge to improve Global Health Financing the MDGs. JAMA, 2004; 2911(21); 2636 - 2638.

7. Killik T. Politics, evidence and the new aid agenda. Dev Policy Rev. 2004; 22: 5 - 29.

8. World Health Organisation Commission on Macroeconomics and Health. Improving Health outcomes of the poor. Report of working group 5. Geneva, Switzerland; WHO, 2002.

9. Report of the international conference on incoming financing 
for development. Monterrey, Mexico, 18 - 22 March, 2002. New York, United Nations; 2002. Available from: http:// uww.unorg/esa/ffd/aconf198 - 11.pdf.

10. Shiffman J. Generating Political Priority for safe motherhood. Afr. J. of Rep. Health. 2004; 8(3): $6-10$.

11. Society of Gynaecology and Obstetrics of Nigeria. Communique from the $38^{\text {th }}$ Annual Scientific Conference of SOGON. Nov 2004. Trop. J. Obstet. Gynecol. 22(1), 2005; 100.

12. The Global Fund to Fight HIVIAIDS, Tuberculosis and Malaria. Global Fund Grants Progress Summary (Rounds 1 - 3). Available at http://www. theglobalfund.org/en/funds-raised/ commitments. Assessed Sept. 2006.

13. UNFPA. Population, Reproductive Health and the millennium Development Goals. UNFPA, New York, USA. 2003.

14. Haines $A$, Cassels $A$. Can the Millennium Development Goals be attained? BMJ. 2004; ISSU $7462,394-7$.

15. Wolfensohn J. Speech by the president of the World Bank James Wolfensohn at a conference on "Making Globalization work for all - the Challenge of delivering the Millennium
Development Goals". HM Treasury and Department for International Development, London, February 16, 2004. Available at http://www.hm-treasury.gov.uk/ documents/international-issues/ global-new-deal/int-gnd-globwolf.cfm. Assessed September 16, 2006.

16. Brown G. Speech by the Chancellor of the Excequer Godon Brown at Conference on "Making Globalization work for all the challenge of delivering the Monterrey consensus". HM Treasury and Department for International Development, London. Feb 16, 2004. Available at http://www. hm-treasury-gov.uk/newsroomand-speeches/press/2004/press12-04-cfm. Assessed September 16, 2006.

17. United Nations. The Millennium Development Goals Report, 2005. Available at http://uww.un. org/millennium goals and http:// millennium indicators.un.org. Assessed September 3, 2006.

18. World Health Organisation. The World Health Report 2003: Shaping the future Geneva, Switzerland. WHO; 2003.

19. Ladipo O.A. The Cairo Consensus and Millennium Development Goals: Reality or Mirage - The Second Olusola Adewale Ojo Memorial Oration. Trop. J. Obstet. Gynaecol. 2005; 22(1): 89 - 99. 